\title{
Corporate Governance Practices and Regulatory Agencies on the Performance of Government Establishments in Sub-Saharan African
}

\author{
Arinze Gabriel Onukwuli \\ School of Business, Federal College of Education (Technical) Umunze, Anambra State, Nigeria
}

\begin{abstract}
The study examines the effect of corporate governance practices and regulatory agencies on the performance of government establishments in Anambra State of Nigeria. Twenty five government establishments in Anambra State were studied using their general managers and Accountants as participants. Spearman's rank correlation coefficient and student t-transformation were used to test for relationship and significant respectively. The results of this study reveal that corporate governance has positive and significant relationship on the performance of corporate governance regulatory agencies. Further results reveal that agreement on corporate governance has positive and significant relationship with lay down standard. The study calls for corporate governance regulatory agencies to discharge their duties without fear of favour and should shun all forms of gratification and render objective report on government organizations. This will redirect government establishment on improving their corporate governance practices, which will enhance their firm value and meet the need of the future generation.
\end{abstract}

Keywords:- Corporate Governance, Corporate Practices, Corporate Mechanism, Regulatory Agencies, Standard

\section{INTRODUCTION}

Corporation around the world are struggling with a new role or concept which is to meet the needs of the present generation without compromising the ability of the next generation to meet their own needs [1]. Therefore the practice of good corporate governance has become a prerequisite for any corporation to be managed effectively in the global market [2]. The attitude which bordered on neglect of corporate governance strategies may have eventually led to the recent high global profile of corporate failures [3]. Anambra State of Nigeria which is a typical Sub-Saharan African State for this study is a major commercial and industrial nerve centre of Nigeria [4]. Ocho in Ejiofor [5] asserted that "the typical Nigerian policeman, teacher, doctor, engineer, postal clerk and others can be relied upon to be lousy, nonchalant, and lackadaisical in his organizational duties. On the other hand when self-employed he can relied upon to be responsible, industrious, highly motivated and untiring". Chukwuemeka et al. [3] work on effect of corporate governance practice on the performance of Government organization in Enugu State opined that there have been several failures and large scale misappropriation of fund in the recent past in Nigeria involving public organizations. Such organizations they indicated include; Anambra State Water Corporation, Cooperative and Commerce Bank, Anambra State Motor Manufacturing Company, Nigeria Coal Corporation and many new generation Banks that could not pass through the recapitalization process.

Corporate failures increases in spite of the fact that there are agencies and regulatory bodies established to oversee corporate governance in Nigeria and ensure compliance with laid down rules and regulation. For instance the federal government of Nigeria through her various agencies have come up with various institutional arrangements to protect the investors of their hard earned investment from unscrupulous management / directors of listed firms in Nigeria. These institutional arrangements, provided in the "code of corporate governance best practice" issued in November, 2003 specified the roles of the board and management; shareholders right and privileges; and role of the Audit committee [6].

\section{REVIEW OF RELATED LITERATURE}

Many variables constitute yardsticks by which corporate governance can be measured in an organization. Kojala [6] identified some of the mechanism as; Board size, board composition, Audit committee and CEO status. Limiting size, to a particular level is generally believed to improve the performance of a firm. Empirical studies on board size seem to provide the same conclusion. Mak and Kusnadi [7] report that small size boards are positively related to high firm performance. 
Kojala, [6] study on corporate governance and firm performance using panel methodology and OLS as a method of estimation indicated that corporate governance has been identified to mean different things to different people. Osisioma and Osisioma [8] defined a well-governed establishment as one that had mostly outside directors, who had no management ties, undertook formal evaluation of its directors and was responsive to investor's request for information on governance issues. OECD in Kojola, [6] defines corporate governance as the system by which business corporations are directed and controlled. The corporate governance structure specifies the distribution of rights and responsibilities among different participants in the corporation such as the broad, managers, stakeholders and spells out the rules and procedures for making decisions on corporate affairs. By so doing this, it provides the structure through which the company's objectives are set and the means of attaining those objectives and monitoring performance. World Council for sustainable development in AlHadded et al. [2] studies on the effect of corporate governance on the performance of Jordanian Industrial Companies using regression analysis, were of the view that corporate governance is basically concerned with the ways in which all parties interested in the well-being of the firm (stakeholders) attempt to ensure that the managers and other insiders are always taking appropriate measures or adopt mechanisms that safeguard the interest of the stakeholders. This also entails business commitment to working with employees, their families, the local community and the society at large to improve their quality of life.

Corporate business governance has both internal and external factors. Internal corporate governance factors relate to the effectiveness of the interaction among a company's management, board, shareholders and other stakeholders, [9]. The external governance factors also play a role in supporting good corporate governance. The external environment both the takeover mechanisms and the law and regulations that enforce the rights of stakeholders and other stakeholders, such a creditors, appropriate oversight by government or other regulatory bodies like - if a corporation is under performing, investors may significantly discount the value of its shares and in severe cases the corporation may be taken over and reorganized to produce acceptable returns for owners [10].

The position of CEO status either separation of the position of the CEO and board chair has positive or negative implication in line with same person occupying the two positions, while entirely independent audit committees may have a lower debt financing cost. Empirical studies on the effect of board membership and structure on firms' value or performance generally shows results either mixed or opposite of what would be expected from the agency cost system [6]. He further indicates that some studies find better performance for firms with board of directors dominated by outsides and others find no relationship between the proportion of outside directors and various performance measures.

Chukwuemeka et al. [3] opined that board as a control mechanism plays an important role in corporate governance, particularly in monitoring and directing management for the achievement of corporate goals which invariably include fostering growth through strategic policy initiative, adding value to shareholding profit maximization, aligning the interests of stakeholders and increasing market share. Therefore the board directs the affairs of the establishment by setting the parameter and ensuring the organization is well run [6].

Interest in corporate governance in Nigeria is associated with regulatory agencies such as the Company and Allied Matters Decree (CAMID) of 1990, which make it mandatory for all companies operating in Nigeria to be registered. The decree also requires all limited liability companies to appoint an auditor to report on their financial statements and abide by all financial reporting process. Further company laws governing business operations in Nigeria include; factory act of 1987, workman's compensation Act of 1987, Annual Credit guideline of Central Bank of Nigeria, Central Bank of Nigeria code of Corporate governance for banks (2006), Corporate governance best practice code of (2003) etc. All these laws aimed at formalizing the concept of accountability by the board of directors, unrestricted disclosures of all aspects of corporate affairs and certification that the published accounts represent a true and fair view of the enterprise affairs [3].

Irrespective of these laws to guide the operation of business establishment in Nigeria, they have not prevented the collapse of many government owned organizations in Nigeria. The reason according to Ugo [11] study on the challenges of business enterprises in South-East of Nigeria is the problem of poor corporate governance standard in Nigeria which lies in poor enforcement.

\subsection{Theoretical Review}

This study anchored on the principal Agent theory and stewardship theory. The principal agent theory developed by Jensen and Meckling [12] states that closely held firms have better economic performance than publicly owned firms. This theory tends to suggest that public enterprises are inefficient due to the fact that there is lack of capital market discipline. Because of lack of market monitoring, managers attempts to pursue their own interest at the expense of enterprises' interest. The significance of this theory to this study is that according to agency theory there is a relationship between ownership structure and economic performance; the cost of monitoring government establishments makes private or closely held firms more economically and more efficient than public owned firms. 
According to stewardship theory, executives' responsibility may neutralize self interest behavior. The theory strongly holds that individuals in management positions do not primarily consider themselves as isolated individuals, instead they consider themselves as part of the firm, merging their ego and sense of worth with the reputation of the firm. With stewardship mode of firm, certain policies follows; firm will spell out in details the role and expectation of managers who are free to pursue their own goals and the managers are naturally company men, who will put the firm ahead of their own goals, hence their freedom are used for the overall good of the firm.

\subsection{Empirical Review}

Brown and Caylor [13] work on corporate governance and firm performance, examines whether firms with weaker corporate governance performance performs more poorly, less profitable, riskier and pay out lower dividends than firms with strong corporate governance. It was found that firms with weaker corporate governance perform more poorly, less profitable, riskier and pay out lower dividend than firms with strong corporate governance. In the study of Chukwuemeka et al. [3] on the effect of corporate government practices on corporate performance of government organization in Enugu State of Nigeria using Spearman raking correlation coefficient. Results showed that there is a relationship between corporate governance and the corporate governance regulatory agencies. Further result shows that corporate governance mechanism in Enugu State does not significantly conform to the lay down standard.

Kojola, [6] examines relationship between corporate governance mechanism and two firm performance measures of a sample of twenty Nigerian listed firms using panel methodology and OLS as a method of estimation. The result provides evidence of a positive relationship. The result provides evidence of a positive relationship between ROE and Board size as well as Chief Executive Status. The results further reveal a positive significant relationship between the two performance measures and board composition and audit committee. Nwosu, [14] study on the impact of corporate performance in Nigeria over the period of 200 - 2011 with special interest in some organization that performs extremely well at the peak of financial meltdown (2008 - 2009). Sixty-eight staff members selected companies were administered with questionnaire and chi-square statistics used in testing the hypothesis. Results show that effective corporate governance have significant impact on corporate performance; that when there is effective corporate governance, organizations' continuous profitability is assured; and that effective corporate governance have significant impact on the survival of organization.

Furthermore, Fujii, Iwata, Kaneko and Manage, [15] studied the relationship between corporate governance and corporate performance. Return on assets (ROA) was used as economic performance indicator and environmental efficiency as environmental performance indicator. The results indicate that there is invited U-shaped relationship between ROA and environmental performance calculated by aggregate toxic risk and that environmental performance increase ROA through both returns on sales and capital turnover improvement. However, a significant positive relationship was observed between financial performance and environmental performance based on $\mathrm{Co}_{2}$ emission.

Onwuchekwa, [16] study on the challenges of attitudinal changes to corporate governance in Nnamdi Azikiwe University using sample of 355 from a population of 3179 University staff. Z-score and Chi-square were utilized for the test of hypothesis. Result shows that the University staff find it difficult to make necessary changes in attitude because the responsible authorities institute governance agent without due consideration to the change required for its effectiveness. According to Chukwuemeka et al. [3] almost all the surviving government establishments in Nigeria today are sick and ailing. They added that these failures raise some fundamental questions such as management style, audit independence, the nefarious practices of board members, ethnics, professionalism and conflict of interest. In line with the above failures, Bies (2004) works on "corporate governance and corporate culture, the intercourse" contends that the sheer scale of fraud, embezzlement and graft observed in some of these failed government establishments has brought into question the reliability and effectiveness of present day operational and compliance control mechanism and financial reporting generally of corporate governance and lay down standard.

The problem of this study is to explore how corporate government regulatory agencies affect corporate government practices in government establishment in Anambra State Nigeria. The main object of the study is to investigate the effect of corporate governance regulatory agencies on corporate government practices in Anambra State. The specific objectives are two-folds:

i. To determine the relationship between corporate governance and performance of corporate governance regulatory agencies.

ii. To determine the relationship between agreement of corporate governance and lay down standard.

In order to achieve these objectives the following questions were answered.

i. Does corporate governance have any relationship with the performance of corporate governance regulatory agencies? 
ii. Does agreement of corporate governance have any relationship with lay down standards?

Arising from the background study subsequent objectives of the study and research questions, the following hypotheses were generated and tested:

$\mathrm{Ho}_{1}$ : There is no significant relationship between corporate governance and the performance of corporate governance regulatory agencies

$\mathrm{Ho}_{2}$ : There is no significant relationship between agreement of corporate governance and lay down standard.

\section{MATERIALS AND METHODS}

Survey research method was used in this study. It involves using a designed corporate governance practice and performance questionnaire. The population of the study forms the sample size; it consists of the general managers and accountants of the twenty-five (25) selected government establishments in Anambra State. All the scale used to measure the construct in this study was derived from instruments designed from previous study in which their reliability and validity were checked and reported. The scale used to measure the corporate governance performance, mechanism and standards had already been constructed, used and tested by Chukwuemeka et al. [3].

Each scale modified to four point likert scale items. Extent varies from 1-4 representing " 1 " for very low extent, "2" for low extent, "3" for high extent and " 4 " for very high extent. Chukwuemeka et al. [3] disclosed reliability through a pilot survey of eight (8) general managers of selected companies in Enugu State using a split-half method which yielded a reliability co-efficient of $73.82 \%$. Spearman's rank correlation was used for data analysis and the choice was necessitated because of the ordinal scale nature of the data.

\section{RESULTS}

The research questions formulated for this study were interpreted using Spearman's Rank Correlation Coefficient while significance of the correlation coefficient was tested by applying t-transformation at $\mathrm{N}-2$ degree of freedom. In other to answer the research question one which states "does corporate governance have any relationship with the performance of corporate governance regulatory agencies"? Table 1 shows the result obtained for answering research question one. The relationship of corporate governance and performance of corporate governance regulatory agencies was positive. The value of rho $=0.80$, therefore, there is a 0.80 rank order correlation between corporate governance and performance of corporate governance regulatory agencies. Furthermore, to answer the research question two which states; "Does agreement on corporate governance have any relationship with lay down standards"? Table 2 shows the result obtained for answering research question two. The strength of relationship is positive (rho $=0.55$ ), therefore, there is a 0.55 rank order correlation between corporate governance and lay down standard.

Hypothesis one which states, "There is no significant relationship between corporate governance and the performance of corporate governance regulatory agencies in Anambra State was tested for significance of rho (.80) by conversion of rho to student t-distribution. The summary of results is shown in Table 1.

Table 1:Summary of results of correlation and t-transformation of correlation coefficient between corporate governance and the performance of corporate governance regulatory agencies.

\begin{tabular}{|c|c|c|c|l|l|l|}
\hline Variables & $\mathbf{N}$ & $\mathbf{R h o}$ & $\mathbf{d f}$ & \multicolumn{1}{|c|}{ Siglevel } & \multicolumn{1}{c|}{$\begin{array}{c}\text { Calculated } \\
\mathbf{t}\end{array}$} & $\begin{array}{c}\text { Critical } \\
\mathrm{T}\end{array}$ \\
\hline $\begin{array}{l}\text { Corporate governance and performance of } \\
\text { corporate governance regulatory agencies }\end{array}$ & 25 & 0.8 & 23 & 0.05 & 6.39 & 2.069 \\
\hline
\end{tabular}

Source: Results of empirical data, 2014.

Table 1 above, shows that $\mathrm{a}, \mathrm{t}=2.069$ is required for significant at .05 level with $\mathrm{df}=23$. Since the calculated $\mathrm{t}$ (6.39) is greater than critical $\mathrm{t}$ (2.069), we reject the null hypothesis and conclude that there is significant relationship between corporate governance and performance of governance regulatory agencies.

Hypothesis two which states, there is no significant relationship between corporate governance with lay down standards in selected government establishment in Anambra State was tested for significance of coefficient rho (.55) by conversion of $\mathrm{r}$ to student $\mathrm{t}$-distribution.

Table 2:Summary of correlation and t-transformation between corporate governance and lay down standard.

\begin{tabular}{|c|c|c|c|c|c|c|}
\hline Variables & n & Rho & df & Siglevel & Calculated & Critical \\
\hline
\end{tabular}




\begin{tabular}{|l|l|l|l|l|l|l|}
\hline & & & & & \multicolumn{1}{|c|}{ t } & T \\
\hline $\begin{array}{l}\text { Corporate governance and lay down } \\
\text { standard }\end{array}$ & 25 & 0.55 & 23 & 0.05 & 3.16 & 2.069 \\
\hline
\end{tabular}

Source: Results of empirical data, 2014.

Table 2 above, shows that $\mathrm{a}, \mathrm{t}=2.069$ is required for significance at .05 level with $\mathrm{df}=23$. Since the calculated $\mathrm{t}$ (3.16) is greater than critical t (2.069), we reject the null hypothesis and conclude that there is significant relationship between corporate governance and the performance of corporate governance regulatory agencies.

\section{DISCUSSION OF RESULTS}

The objective of this paper is to explore the effect of corporate governance regulatory agencies and corporate government practices on performance of government establishment in Anambra State, Nigeria. Corporate governance which is previously seen as the foundation of good corporate performance has been neglected by corporate bodies for a considerable length of time. After the test of hypotheses, the research study proves relationship between corporate governance and the performance of corporate governance regulatory agencies; and corporate governance and lay down standard.

The first hypothesis states, there is no significant relationship between corporate governance and the performance of corporate governance regulatory agencies in Anambra State was rejected. This shows that corporate governance and the performance of corporate governance regulatory agencies in Anambra state significantly correlate. The finding has contradicted with the works of Chukwuemeka et al., [3] on the effect of corporate governance practices on the performance of government organization in Enugu State using Spearman's rank correlation. Results indicated that there is a positive but insignificant relationship between corporate governance and the performance of corporate governance regulatory agencies.

The second hypothesis states that "there is no significant relationship between agreement of corporate governance and lay down standard was rejected. The finding of this study agrees with the works of Chukwuemeka et al., [3] that corporate establishment does not conform to standard.

The findings of the study will serve as an added contribution to the existing work of other authors on corporate governance and why government organizations are not performing well, while their counterparts in the private sector are doing well. For instance, why is G.U.O Transport Company, Ekenedilichukwu Transport Company both of private sector organizations in Anambra State perform better than Transport Corporation of Anambra State? It is important at this juncture to suggest that more research should be conducted on using many public and private organizations. More so, further studies to be carried out in order to investigate factors that affect corporate governance and corporate governance regulatory agencies in Anambra State, Nigeria.

\section{CONCLUSION AND RECOMMENDATIONS}

Corporate governance mechanisms assure investors in the corporations that they will receive adequate returns on their investments. The study has shown that the relationship between corporate governance practices on the performance of government organization in Anambra State was positive and significant. This paper calls for corporate governance regulatory agencies to discharge their duties without fear or favour and should shun all forms of gratification and render objective report on government organizations. Finally, it is recommended that Government establishments should focus on improving their corporate governance practice, which will enhance their firm value and meet the need of the future generation.

\section{REFERENCES}

[1]. B.Y. Abiodun, The impact of corporate social responsibility on firms' profitability in Nigeria; European Journal of Economics, Finance and Administrative Science, (45), 2012, 39-50.

[2]. W.M. Al-Haddad, S.T. Alzuraquan, and F.J. Al-Sufy, The effect of Corporate governance on the performance of Jordanian Industrial Companies: An Empirical study on Amman Stock Exchange, International Journal of Humanities and Social Science, (1), 2011, 43-56.

[3]. E. Chukwuemeka, N. Nzewi, and E.U. Ezenyilimba, The effect of corporate governance practices on the performance of government organizations: A study of Enugu State of Nigeria, Journal of Basic, Applied, Sci. res., 1 (7), 2011, 649-656.

[4]. E.I. Idemobi, The problem of sustaining the growth of small and medium enterprises in Sub-Saharan African context, African Journal of Social Sciences, 2(1), 2012, 15-24.

[5]. P.N.O. Ejiofor, Management style in a result oriented services: managing people and for desired results, Imo State of Nigeria Public Service Lecture, series (1), 1985, 1-45.

[6]. S.O. Kajola, Corporate Governance and Firm Performance: the case of Nigeria listed firms, E pean Journal of Economics, Finance and Administrative Science, (14), 2008, 16-29.

[7]. V. Mak, and Y. Kusnadi, Y. "Size really matters: Further evidence on the negative relationship between board size and firm value", Pacific-Basin Finance Journal, (13), 2005, 301-318.

[8]. B.C. Osisioma, H.E. and Osisioma, Management Practice Manual for the Professional Management Student, ( $2^{\text {nd }}$ edition), 2002, Enugu: SNAPPS.

[9] D. Denis, and J. McConnell, Internal Corporate Governance, 2002, SSRN Working Paper, 320121.

[10]. J. Novikova, The Impact of Internal Governance System on Firms Innovative Activities, Journal of Finance, (2), 2004, 215-286. 
[11]. D.S. Ugo, "Challenges of Business Enterprises in the South Eastern Nigeria", Journal of Policy and Development Studies, 4 (3), 2010, 45-55.

[12]. M.C. Jensen, W.H. and Meckling, W. H. Corporate Governance and Economic Democracy, 1976, retrieved on $2^{\text {nd }}$ June, 2012 from www.en.wikpedia.org/wiki/michael-jensen.

[13]. S. Brown, and D. Caylor, Corporate Governance and Firm performance, European Financial Journal, (16), 2004, 301-312.

[14]. H.E. Nwosu, H. E. The impact of Corporate Governance on Corporate Performance, A Study of selected companies in Nigeria, Department of Business Administration 2012 Conference Proceeding, Business Mentoring and Macro Economic Development in Africa: Strategies and Options, Nnamdi Azikiwe University, Awka, (1), 2012, 272-287.

[15]. H. Fujii, K. Iwata, S. Kaneko, and S. Manage, Corporate Environmental and Economic Performance of Japanese Manufacturing Firms: Empirical study for Sustainable Development, Retrieved from http://mpra.ub.unimuenchen,de on $20^{\text {th }}$ June, 2012.

[16]. F.C. Onwuchekwa, Challenges of Attitudinal Changes to Corporate Governance in Nigeria: A study of Nnamdi Azikiwe University Awka, Department of Business Administration, Nnamdi Azikiwe 2012 Conference proceeding on Business mentoring and Macroeconomic Development in Africa: Strategies and Options (1), 2012, 390-400

[17]. V. Bies, Corporate governance and corporate culture: the intercourse, International Journal of Management, 66 (2), 2004, 103-112. 